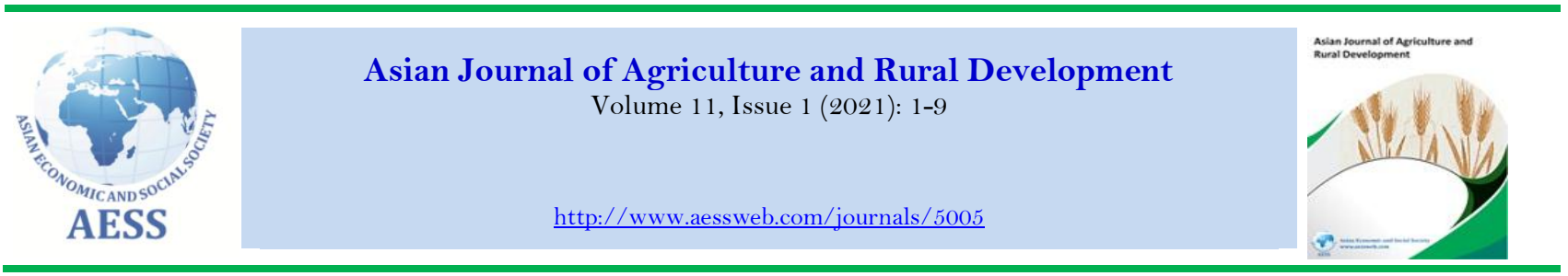

\title{
RECOMBINANT PROTEIN FOLIAR APPLICATION ACTIVATES SYSTEMIC ACQUIRED RESISTANCE AND INCREASES TOLERANCE AGAINST PAPAYA DIEBACK DISEASE
}

\author{
Norliza Abu-Bakara \\ iD Nor Mustaiqazah Juri ${ }^{b}$ \\ iD Ros Azrinawati Hana Abu- \\ Bakar $^{c}$ \\ (iD) Mohd Zulfadli Sohaime ${ }^{\mathrm{d}}$ \\ (iD) Rafidah Badrun \\ Johari Sarip ${ }^{\mathrm{f}}$ \\ Mohd Azhar Hassang \\ Khairulmazmi Ahmad ${ }^{\mathrm{h}}$
}

\author{
a,b,c,eBeBiotechnology and Nanotechnology Research Centre, Malaysian Agricultural Research \\ and Development Institute, Malaysia. \\ ${ }_{{ }^{t}}$ Horticulture Research Centre, Malaysian Agricultural Research and Development \\ Institute, Malaysia. \\ ${ }^{n}$ Department of Plant Protection, Faculty of Agriculture, Universiti Putra Malaysia, \\ Malaysia. \\ -
}

\begin{abstract}
Similar to animals, plants possess 'immune memory' in response to invading pathogens that lead to enhanced defense reaction following pathogen exposure. Systemic acquired resistance (SAR) is a well-characterized type of plant immunity and is associated with coordinated expression of a set of pathogenesis-related (PR) genes and proteins also known as SAR markers. Induction of SAR in plants was shown to be initiated by group of chemicals and biological compounds known as SAR inducers that can be used for the management of important plant diseases. Elucidation and characterization of potential SAR inducers as potential elicitors that can protect papaya from the papaya dieback disease pathogen were carried out using HRPX protein, which was produced as a recombinant protein in an Escherichia coli system. Disease severity analysis in a glasshouse experiment indicated lower disease infection rates in the HRPX-treated plants than in water-treated plants. Selected SAR-associated defense gene expression was also shown to increase in treated plants, via quantitative real-time PCR analysis, confirming enhanced disease response through SAR activation. In this report, the selected recombinant protein was shown to activate the SAR mechanism in papaya for increased tolerance against papaya dieback disease, which was proven via physiological and molecular analysis.
\end{abstract}

Contribution/Originality: This study documents the process utilized to produce Erwinia mallotivora HRPX recombinant protein using a heterologous E. coli recombinant system. The recombinant protein produced was later tested and assessed for its ability to act as a systemic acquired resistance (SAR) inducer to increase papaya tolerance against papaya dieback disease.

DOI: $10.18488 /$ journal.ajard.2021.111.1.9

$\operatorname{ISSN}(\mathrm{P}):$ 2304-1455/ ISSN(E): 2224-4433

How to cite: Norliza Abu-Bakar --- Nor Mustaiqazah Juri --- Ros Azrinawati Hana Abu-Bakar --- Mohd Zulfadli Sohaime --- Rafidah Badrun ---Johari Sarip --- Mohd Azhar Hassang --- Khairulmazmi Ahmad (2021). Recombinant Protein Foliar Application Activates Systemic Acquired Resistance and Increases Tolerance against Papaya Dieback Disease. Asian Journal of Agriculture and Rural Development, 11(1), 1-9. 10.18488/journal.ajard.2021.111.1.9 


\section{INTRODUCTION}

Carica papaya - widely known as papaya - is a tropical plant that is highly associated with its appealing fruit and medicinal properties arising from various parts of the plant. Papaya remains one of the most popular species in the Caricacae family, part of the angiosperm group within the kingdom Plantae (Evans \& Ballen, 2012). Papaya was once widely grown in Malaysia. Malaysian consumers prefer the fruit for daily consumption while the leaves, which contain considerable levels of flavonoids, alkaloids, and phenolic compounds, are used as a remedy for fevers, dengue fever, cardiovascular diseases, cancer, malaria, asthma, ulcers, eczema, hypoglycemia, and hyperlipidemia (Anuar, Zahari, Taib, \& Rahman, 2008; Aziz, Kassim, Kasim, Haque, \& Rahman, 2015; Dharmarathna, Wickramasinghe, Waduge, Rajapakse, \& Kularatne, 2013; Otsuki et al., 2010). Even though the demand for papaya is high, production in Malaysia is severely threatened by the emergence of diseases caused by bacteria, viruses, phytoplasma and fungi (Rabu \& Mat, 2005). Since 2006, the phytopathogen Erwinia mallotivora has led to a decline of the papaya industry in Malaysia despite being the second-highest exporter globally in 2004, just behind Mexico, with a total production of 58,149 MT covering more than $21 \%$ of the global papaya trade market (Anon, 2009). Commercial varieties, including Sekaki, Solo, and Eksotika, are very susceptible to the disease, thus making it harder for the papaya industry in Malaysia to be revitalized and attain its former prominence.

Papaya dieback disease in Malaysia is caused by E. mallotivora, a flagellar, biotrophic phytopathogenic bacterium (Noriha, Hamidun, \& Indu, 2011). The disease has led to devastating effects in term of yield loss and national incomes for both domestic and international trade. Infected papaya fruit exhibits lesions and spots on the leaves and crown, eventually accompanied by water damage to the stem (Gardan, Christen, Achouak, \& Prior, 2004). Fruit quality is also affected by defoliation and spots and blemishes that downgrade its quality, rendering it unsuitable for consumption and export. Eventually the infected plant will succumb to the disease, resulting in death (Mohd Taha et al., 2019).

Holistic approaches have been taken by the Malaysian government and researchers to curb the widespread transmission of this disease (Abu Bakar et al., 2017). During the early spread of this disease, infected trees were destroyed and crop rotation practices implemented (Chan \& Baharuddin, 2010). Interim measures were introduced, such as systematic farming; changes in the management and operation of farms, including limiting vehicular access to farmland, cleaning of farm equipment, and farm workers' clothing; and monitoring of drainage and drainage systems' processes (Ahmad et al., 2014; Mohd Taha et al., 2019). Daily supervision and the process of eradication of suspected disease on the farm were also carried out regularly. Advancement in disease management strategies, supported by plant-pathogen interaction studies, has advanced alternative crop protection technology by utilizing the host systemic acquired resistance (SAR) mechanism to control phytopathogen attack (Dangl, Horvath, \& Staskawicz, 2013). Accumulation in the plant of the hormone salicylic acid (SA) is closely linked with SAR induction (Gao, Zhu, Kachroo, \& Kachroo, 2015). These measures are supported by research on the usage of chemicals and synthetic chemicals such as SA and jasmonate, and of virulent, avirulent, and non-pathogenic microbes (Birkenbihl, Liu, \& Somssich, 2017). The introduction of SAR is closely connected with increased oxidative cell burst, changes in cell wall composition, de novo synthesis of compounds like phytoalexin, and increased expression of PR proteins (Fu \& Dong, 2013). Plants treated with various SAR inducers have been demonstrated to exhibit increased tolerance, and sometimes increased resistance, with observation of subsequent pathogen challenge resulting in a stronger elicitation of the plant defense mechanism (Bektas \& Eulgem, 2015; Jung, Tschaplinski, Wang, Glazebrook, \& Greenberg, 2009). The application of such SAR inducers has paved the way for plant disease control and management and, specifically, as an alternative crop protection strategy in managing papaya dieback disease.

Type III secretion systems are widely used by phytopathogens to deliver effectors into their host cells to cause disease (Alfano \& Collmer, 2004; Chen et al., 2017; Göhre \& Robatzek, 2008). Natriuretic peptide receptor 1 (NPRI) is essential in plants for the expression of PR genes involved in SAR activation and defense of the plant against invasion and attack, through increased expression of PR genes (Cao, Glazebrook, Clarke, Volko, \& Dong, 1997; Kim \& Delaney, 2002). As a key transcriptional regulator of SA signaling, NPR1 is important in the induction of host systemic immunity. Overexpression of a rice $N P R 1$ homolog led to constitutive activation of the defense response and hypersensitivity to light (Chern, Fitzgerald, Canlas, Navarre, \& Ronald, 2005). Type III effectors have been shown to interact with NPRI to destabilize host immunity and thus have the potential as target molecules to stimulate the signaling molecule for plant immunity, together with defense onset and commencement (Chen et al., 2017; Jones \& Dangl, 2006).

Our previous study indicated that HRPX, an E. mallotivora Type III effector, was upregulated in in vitro cultures of E.mallotivora stimulating the expression of pathogenicity (hrp) and virulence proteins of the pathogen. This finding was later confirmed via real-time quantitative polymerase chain reaction (q-PCR) analysis (Abu Bakar et al., 2017). Thus, the present study was conducted to investigate the effectiveness of a selected E. mallotivora Type III effector, HRPX, produced as a recombinant protein to aid in the control of papaya dieback disease. We aimed to determine its effectiveness as a SAR inducer and understand the molecular events underlying the SAR process regarding the induced resistance process.

\section{MATERIALS AND METHODS}

\subsection{Plants, Plasmids, Bacterial Strains, and Growth Conditions}

Carica papaya (Eksotika I) seedlings were grown in polybags filled with mixed compost. The plants were grown in a glasshouse at $27^{\circ} \mathrm{C}$ with a 12 -h day/night cycle. Plasmid pGEM-T (Promega) and pET32b (Novagen) were respectively used as cloning and expression vector. The E. coli strains Top10 (Invitrogen, USA) and BL21 (DE3) 
were used as cloning and expression host, respectively. Both E. coli strains were grown in LB broth medium supplied with $100 \mu \mathrm{g} / \mathrm{ml}$ of ampicillin at $37^{\circ} \mathrm{C}$. E. mallotivora was cultured in LB broth at $28^{\circ} \mathrm{C}$.

\subsection{Isolation and Cloning of HRPX}

Total RNA from overnight culture $\left(28^{\circ} \mathrm{C}\right)$ of E. mallotivora was extracted using a total RNA extraction kit (Qiagen, USA) following the manufacturer's protocol, followed by cDNA synthesis using an iScript cDNA Synthesis Kit (Bio-Rad, USA). PCR was performed using a predesigned, specific HRPX primer pair and other PCR components from Promega (USA). The primer sequences were HRPX forward, 5'GGATCCGATGCAATTTTCCGAGCGACAT-3' HRPX and reverse, AAGCTTTCCATTGTACGATTCCAAATC-3', with an expected amplicon size of $\sim 1.5 \mathrm{kbp}$. The BamHI and HinDIII sites were added to facilitate the cloning processes. The total $20 \mu \mathrm{L}$ reaction mixture contained $2 \mu \mathrm{L}$ of $10 \times$ PCR buffer, $2 \mu \mathrm{L}$ of $\mathrm{MgCl}_{2}(20 \mathrm{mM})$, $0.5 \mu \mathrm{L}$ of each $\mathrm{dNTP}(2.5 \mathrm{mM}), 1 \mu \mathrm{L}$ of DNA, $0.6 \mu \mathrm{L}$ of each primer, and $1 \mu \mathrm{L}$ of Pfu DNA polymerase $(5$ units $/ \mu \mathrm{L})$. The program used was an initial incubation time of 3 min at $94^{\circ} \mathrm{C}, 30$ cycles of 30 $\mathrm{s}$ at $94^{\circ} \mathrm{C}, 30 \mathrm{~s}$ at $60^{\circ} \mathrm{C}$ for annealing, and $30 \mathrm{~s}$ at $72^{\circ} \mathrm{C}$ for extension, followed by a cycle of final elongation for $7 \mathrm{~min}$ at $72^{\circ} \mathrm{C}$.

The PCR product was visualized by $1 \%$ agarose gel electrophoresis. The band was excised from the gel, purified, and cloned into pGEM-T Easy vector (Promega) according to the manufacturer's protocol, followed by transformation into competent TOP10 E. coli via the heat shock method. Transformed cells were plated on LB medium supplemented with $100 \mu \mathrm{g} / \mu \mathrm{L}$ ampicillin and $20 \mu \mathrm{g} / \mathrm{mL}$ X-gel. White colonies were selected for colony PCR and plasmids of positive clones were extracted, double digested with BamHI and to confirm the presence of the insert (HRPX). The digested HRPX fragment was subcloned into the pET32b (Novagen) expression vector with $6 \times$ His tags downstream and transformed into a competent BL21 E. coli expression strain. Transformed cells were plated on $\mathrm{LB}$ medium supplemented with $100 \mu \mathrm{g} / \mu \mathrm{L}$ ampicillin.

\subsection{Expression and Purification of HRPX Recombinant Protein}

A colony of pET32b/HRPX-transformed BL21 was cultured in $5.0 \mathrm{~mL}$ of LB broth medium supplemented with $100 \mu \mathrm{g} / \mu \mathrm{L}$ ampicillin overnight at $37^{\circ} \mathrm{C}$. The culture was transferred into $400 \mathrm{~mL}$ of LB broth medium containing $100 \mu \mathrm{g} / \mathrm{mL}$ ampicillin and was grown at $37^{\circ} \mathrm{C}$ to $\mathrm{OD}_{600}$ 0.5. To induce expression, isopropyl-B-Dthiogalactopyranoside (IPTG) was added to a final concentration of $0.5 \mathrm{mM}$ to the cell culture and was grown for a further $6 \mathrm{~h}$ before harvesting by centrifugation at $2,500 \times g$ for $15 \mathrm{~min}$.

The bacterial pellet was resuspended and lysed with $10 \mathrm{~mL}$ of Bugbuster reagent (Novogen) supplemented with a tablet of protease inhibitor (Thermo Fisher, USA). The lysed cell suspension was centrifuged at $20,000 \times g$ for 30 min at $4{ }^{\circ} \mathrm{C}$. The pellet was resuspended in $10 \mathrm{~mL}$ of inclusion bodies (0.5 M Tris $\mathrm{pH} 7.4,75 \mathrm{mM} \mathrm{NaCl}$, and $10 \%$ glycerol) supplemented with $0.5 \%$ triton and was rotated for $15 \mathrm{~min}$ at $4{ }^{\circ} \mathrm{C}$ before centrifuging at $20,000 \times \mathrm{g}$ for 30 min at $4{ }^{\circ} \mathrm{C}$. The pellet was then resuspended in $10 \mathrm{~mL}$ of solubilization buffer $(50 \mathrm{mM}$ Tris-Cl pH $7.4,150 \mathrm{mM} \mathrm{NaCl}$, $8 \mathrm{M}$ urea) supplemented with a tablet of protease inhibitor and was rotated overnight at $4{ }^{\circ} \mathrm{C}$. Then, the protein suspension was centrifuged at $3,500 \times g$ for $15 \mathrm{~min}$ at $4{ }^{\circ} \mathrm{C}$ and the supernatant was collected for purification using a Ni-NTA column (His tag protein purification) by the Acta Prime Chromatography System. The purified HRPX protein was quantified following the Bradford method (Quick Start ${ }^{\mathrm{TM}}$ Bradford Protein Assay, BioRad) using bovine serum albumin as standard (Bradford, 1976).

To visualize the purified protein, approximately $20 \mu \mathrm{L}$ was mobilized on two sets of sodium dodecyl sulfate polyacrylamide gel electrophoresis (SDS-PAGE), with polyacrylamide concentration of 12 and $5 \%$ for separation and stacking gel, respectively. One set of the gel was imaged using Coomassie Brilliant Blue R250 while the other was presented for Western Blot analysis. Briefly, the protein was transferred to a polyvinylidene fluoride membrane. The membrane was blocked with blocking buffer before probing with an anti-His antibody, with gentle agitation for $2 \mathrm{~h}$ at $37^{\circ} \mathrm{C}$. After three washes with $1 \times$ Tris Buffered Saline with Tween 20 (TBST), the membrane was further incubated with anti-mouse $\operatorname{IgG}$ alkaline phosphatase conjugate for $2 \mathrm{~h}$ at $37^{\circ} \mathrm{C}$. The membrane was washed again with $1 \times$ TBST, followed by incubation with the substrate solution (BCIP/NBT) until the bands appeared.

\subsection{Plant Treatment}

At 4 months of growth, papaya seedlings were sprayed with HRPX protein formulation three times at 1-week intervals. For control, plants were treated with water. The experimental design adopted a complete randomized design with ten replicates for each sprayed treatment. Inoculation of E. mallotivora in papaya plants was conducted 1 week after the final formulation treatment. E. mallotivora was cultured in LB broth and grown at $28^{\circ} \mathrm{C}$ in an incubator shaker to $\mathrm{OD}_{600}$ 1.0. About $10 \mathrm{~mL}$ of E. mallotivora culture at a concentration of $1 \times 10^{6}$ colony-forming units (CFU) was injected into all seedlings at the level of the third node from the shoot.

\subsection{Disease Index and Statistical Analysis}

Evaluation of the progression of E. mallotivora infection was made through disease severity (DS) statistical analysis, with severity evaluated using a 5-point scale: $0=$ symptomless, $1=$ leaf vein blackening, $2=1$ leaf vein blackening + slight wilting, $3=$ leaf stalk wilting, $4=$ stem blackening, and $5=$ plant death. Scoring was applied from days 3 to 21 post inoculation at 3-day intervals. The disease severity index (DSI) was computed based on a previous study (Abu Bakar, Mohd Zulfadli, Juri, \& Johari, 2018). The experiments were repeated three times, and the 
data were analyzed using analysis of variance followed by comparison means using Duncan multiple range tests (Samsuddin et al., 2018).

\subsection{Leaf Sampling and Expression Profiling of PR Genes}

Sampling of leaves was conducted on day 20 after the first application of HRPX foliar treatment. All plant samples were immediately immersed in liquid nitrogen and stored at $-80^{\circ} \mathrm{C}$ until further analysis. Leaf tissues were ground to a fine powder and extraction of total RNA was conducted using the GeneJET Plant RNA Purification kit (Thermo Fisher Scientific, USA) following the manufacturer's instructions. Removal of genomic DNA contamination was performed using DNase I (Thermo Fisher Scientific, USA).

Two micrograms of RNA was transcribed into cDNA using the iScript cDNA Synthesis Kit (Bio-Rad, USA) following the manufacturer's protocol. Synthesized cDNA was used as template for real-time PCR for four reported PR genes in papaya (NPR, PRIB, PRID, and Osmotin) (Norliza, Rafidah, \& Mohd, 2016) and two housekeeping genes (actin and 4OSRNP) to normalize expression fold.

DA list of the primers used as given in Table 1. Real-time PCR was performed using a 96-well-plate BIO-RAD CFX96 Real-time PCR System thermo cycler (Bio-Rad, Berkeley, CA, USA). The PCR reaction per well contained 2 $\mu \mathrm{g}$ of first-strand cDNA, 0.4 $\mu \mathrm{M}$ forward and reverse primers, and $1 \times$ master mix of SensiFAST SYBR No-Rox Kit (Bioline, UK). For negative control, sterile distilled water was added to the master mix rather than cDNA. Ten microliters of PCR reaction components were transferred to the wells, in triplicate. The PCR condition was set to $95^{\circ} \mathrm{C}$ for $2 \mathrm{~min}, 40$ cycles at $95^{\circ} \mathrm{C}$ for $15 \mathrm{~s}$, and $60^{\circ} \mathrm{C}$ for $1 \mathrm{~min}$.

Table 1. List of primers used.

\begin{tabular}{l|l|l|c}
\hline Gene & Forward primer & Reverse primer & Size (bp) \\
\hline Osmotin & TCTACTTGCCAAGCTCCAAA & GGGCAATTGTTCCTTACTTGA & 132 \\
\hline PR1d & CTCGGTTCGTTTAGGGTGTG & TGGATTATTGGGAAACTTTTATTGA & 155 \\
\hline PR1b & CGTCCTTTTGGTTTCTGGGA & TTTTTGTTCGTTACTCACACATGA & 151 \\
\hline NPR & CGCCTTTCAGAATCCAAGAG & ATCATGTTCCAGACGTGCAA & 155 \\
\hline Actin & TTCCACTATGTTCCCTGGTATT & TCCTATCCAGACGCTGTATTTC & 119 \\
\hline 40SRNP & TGGCAAAGCCTACAAAGACTATCA & AGGAATGGGAAGGGAGGGAGAT & 78 \\
\hline
\end{tabular}

\section{RESULTS AND DISCUSSION}

\subsection{In Silico Characterization of HRPX}

A previous study showed that the Type III Secretion System plays a major role during E. mallotivora pathogenesis (Juri et al., 2020). Hairpin or hrp proteins are part of the Gram-negative plant-pathogenic Type III Secretion System and have been shown to induce resistance in plants against various pathogens (Fontanilla, Montes, \& De, 2005; Kim, Jeon, Oh, Moon, \& Hwang, 2004; Liu et al., 2010).

Increased expression of E. mallotivora HRPX genes was shown during infection, which was further validated using real-time analysis (Abu Bakar et al., 2017; Juri et al., 2020). This gene was hypothesized to be a candidate gene for induction of SAR during subsequent infection. Thus research was initiated to further characterize the $H R P X$ gene from E. mallotivora, which involved in silico characterization and protein function in induction of SAR for the management of papaya dieback disease.

The domain analysis of E. mallotivora's HRPX protein sequence (ORF) showed that this hrp protein has a signal transduction histidine kinase motif, located at 240-483 of the c-terminal end of its amino acid sequence (Figure 1). Meanwhile, a BLASTp homology search in Genbank nonredundant databases revealed that this protein has the highest identity (80-99.8\%) with PAS domain-containing sensor histidine kinase and PAS domain S-box protein from several Pantoea and Erwinia species (Table 2).

PAS domain-containing sensor histidine kinase is present in archaea, eubacteria, and eukarya. It is part of a twocomponent system (TCS), functioning as a protein kinase that phosphorylates a target protein in response to various signals. In bacteria, TCSs are pairs of proteins with a modular structure comprising a sensing (input) domain at the N-terminal, and a C-terminal conserved kinase core (transmitter) domain that interacts with a response regulator protein $(\mathrm{RR})$, where the $\mathrm{RR}$ protein is usually a transcription factor. Activation of the RR triggers specific downstream responses (Merighi, Majerczak, Stover, \& Coplin, 2003).

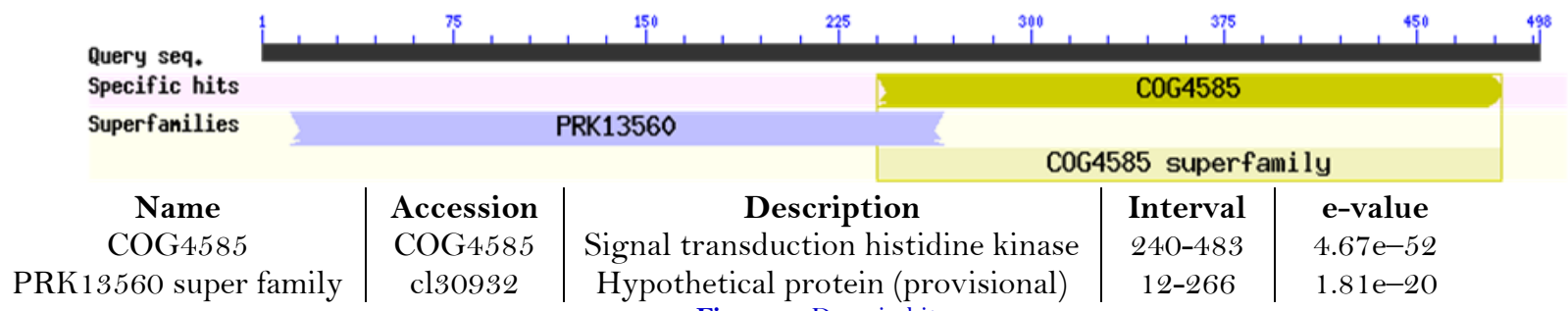

Figure 1. Domain hits. 
Table 2. BLASTp analysis of E. mallotivora HRPX.

\begin{tabular}{l|c|c|c|c}
\hline Description & $\begin{array}{c}\text { Query cover } \\
(\%)\end{array}$ & e-value & Per. ident. (\%) & Accession no. \\
\hline $\begin{array}{l}\text { PAS domain-containing sensor histidine } \\
\text { kinase (E. mallotivora) }\end{array}$ & 79 & 0.0 & 100.00 & WP_034936536.1 \\
\hline $\begin{array}{l}\text { PAS domain-containing sensor histidine } \\
\text { kinase (Pantoea sp. VS1) }\end{array}$ & 79 & 0.0 & 99.80 & WP_088518176.1 \\
\hline $\begin{array}{l}\text { PAS domain S-box protein (Erwinia } \\
\text { psidic) }\end{array}$ & 79 & 0.0 & 91.57 & WP_124231880.1 \\
\hline $\begin{array}{l}\text { PAS domain S-box protein (Pantoea } \\
\text { agglomerans) }\end{array}$ & 79 & 0.0 & 90.36 & WP_158150184.1 \\
\hline $\begin{array}{l}\text { PAS domain S-box protein (Pantoea } \\
\text { agans) }\end{array}$ & 79 & 0.0 & 90.08 & WP_061060958.1 \\
\hline $\begin{array}{l}\text { PAS domain S-box protein (Erwinia } \\
\text { tracheiphila) }\end{array}$ & 79 & 0.0 & 86.37 & AXF77209.1 \\
\hline $\begin{array}{l}\text { PAS domain-containing sensor histidine } \\
\text { kinase (E. tracheiphila) }\end{array}$ & 79 & 0.0 & 86.17 & WP_016191016.1 \\
\hline HRPX P. agglomerans pv. gypsophilae & 77 & 0.0 & 84.98 & AAF76212.1 \\
\hline $\begin{array}{l}\text { PAS domain S-box protein (Pantoea sp. } \\
\text { paga) }\end{array}$ & 79 & 0.0 & 83.84 & WP_143991671.1 \\
\hline $\begin{array}{l}\text { PAS domain-containing sensor histidine } \\
\text { kinase (Erwinia amylovora) }\end{array}$ & 79 & 0.0 & 81.17 & WP_004155353.1 \\
\hline $\begin{array}{l}\text { PAS domain-containing sensor histidine } \\
\text { kinase (Erwinia tasmaniensis) }\end{array}$ & 79 & 0.0 & 81.38 & WP_012440278.1 \\
\hline $\begin{array}{l}\text { PAS domain-containing sensor histidine } \\
\text { kinase (Erwinia piriflorinigrans) }\end{array}$ & 79 & 0.0 & 80.97 & WP_023653749.1 \\
\hline $\begin{array}{l}\text { PAS domain-containing sensor histidine } \\
\text { kinase (Erwinia pyrifoliae) }\end{array}$ & 79 & 0.0 & 81.17 & WP_012669312.1 \\
\hline $\begin{array}{l}\text { PAS domain S-box protein (Erwinia sp. } \\
\text { Ejp617) }\end{array}$ & 79 & 0.0 & 80.97 & WP_014543259.1 \\
\hline $\begin{array}{l}\text { PAS domain S-box protein (Pantoea sp. } \\
\text { PNA 03-3) }\end{array}$ & 77 & 0.0 & 82.19 & WP_110268456.1 \\
\hline
\end{tabular}

\subsection{Cloning, Expression, and Purification of Recombinant HRPX}

A specific primer was designed to amplify HRPX from E. mallotivora (Figure 2A). The amplified HRPX gene was cloned into pGEM-T Easy vector and the presence of the HRPX in the vector was confirmed by colony PCR (Figure 2B). The integrity of the recombinant vector pGEM-T/HRPX was confirmed by double digestion using restriction enzymes BamHI and HinDIII (Figure 2C). The digested HRPX fragment was then successfully subcloned into the expression vector pET32b (Novagen), where the identity and orientation of HRPX in the construct was confirmed by sequencing. Cloned HRPX gene sequencing showed 100\% homology with the reference sequence. Expression of the $H R P X$ gene in the pET-20b expression vector was induced in the presence of IPTG. Proteins in the supernatant and cell lysate pellet were analyzed using SDS-PAGE (data not shown), with the majority of the expressed protein being detected in the pellet of cell lysate. The recombinant protein was successfully purified using a Ni-NTA column (Figure 3), having a molecular weight of approximately $50 \mathrm{kDa}$. Approximately $50-100 \mathrm{mg}$ of pure recombinant protein is normally obtained from every $2-1$ culture of LB broth expression culture, induced with $0.5 \mathrm{mM} \mathrm{IPTG}, 37^{\circ} \mathrm{C}$ for $2 \mathrm{~h}$. The amount of pure $H R P X$ protein obtained was sufficient for the foliar application treatment of papaya seedlings to determine the effect of SAR inducement for increased tolerance to papaya dieback disease.
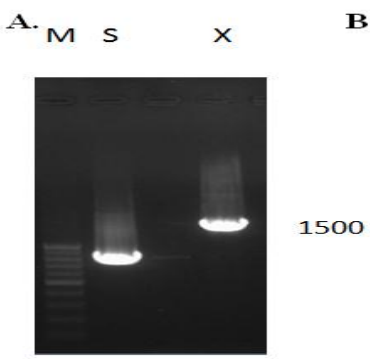

B.

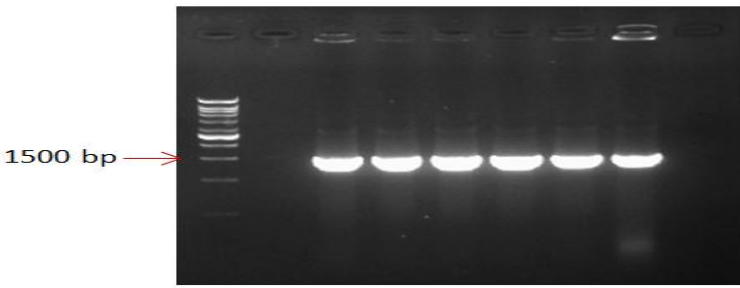

C.

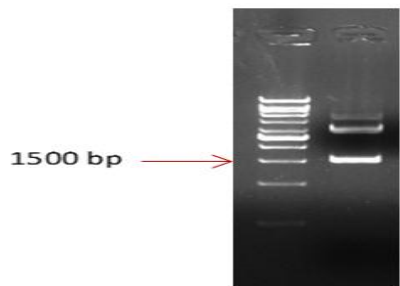

Figure 2. (A). Amplification of HRPX gene via PCR. A single gene was amplified from the PCR reaction. The band was excised, purified, and cloned into pGEM-T Easy vector. (B) Colony PCR. A single band was detected at the size expected for HRPX. M: 1-kb marker; 1-6: colonies; C: control (PCR reaction without colony). (C) The plasmid from the transformed colony was digested with the restriction enzymes BamHI and HinDIII, to determine the presence of the insert. M: 1-kb marker; X: HRPX. 
A.

$\begin{array}{lllllllll}M & 1 & 2 & 3 & 4 & 5 & 6 & 7 & 8\end{array}$

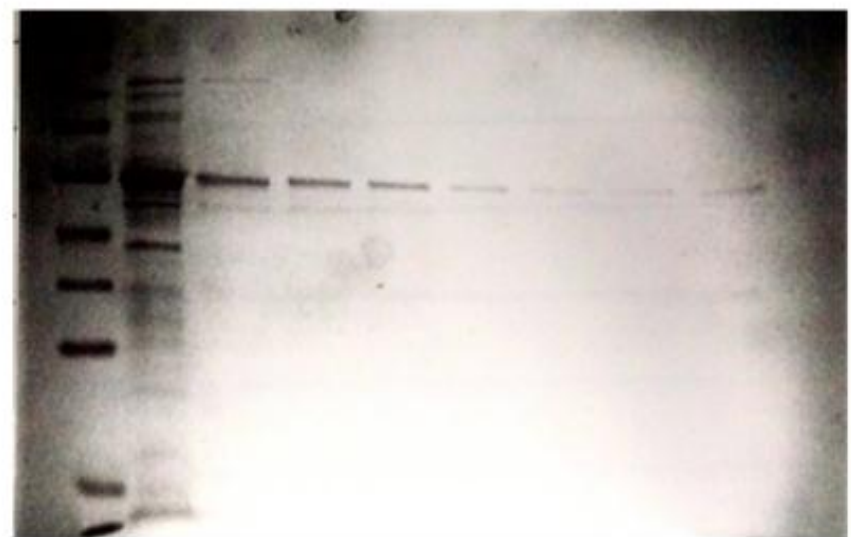

B.

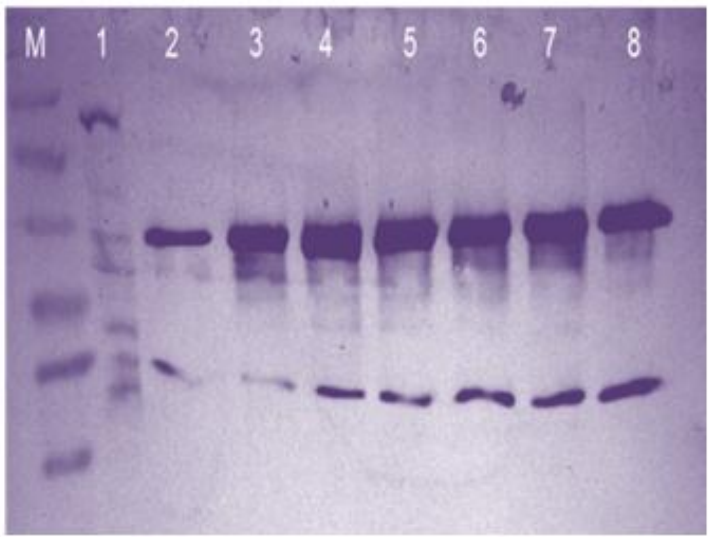

Figure 3. (A) SDS-PAGE and (B) Western blot showing the purity of HRPX protein after purification using a Ni-NTA affinity column. M: 1-KB marker; 1: HRPX before purification; 2-8: fractions collected after purification.

\subsection{Pathogen Inoculation, Plant Disease Severity Assessment, and Profiling of SAR-responsive Genes}

To investigate the capability of HRPX recombinant protein in enhancing papaya resistance against dieback pathogen, both the HRPX-sprayed and control plants were injected with approximately $10 \mathrm{~mL}$ of E. mallotivora culture at a concentration of $1 \times 10^{6} \mathrm{CFU}$, at the third node from the shoot. Overall, although both control and HRPX-sprayed plants were infected, from days 3-13 reduced disease symptoms were shown by the latter compared to the former. By day 13, control plants were totally infected and died (Figure 4).

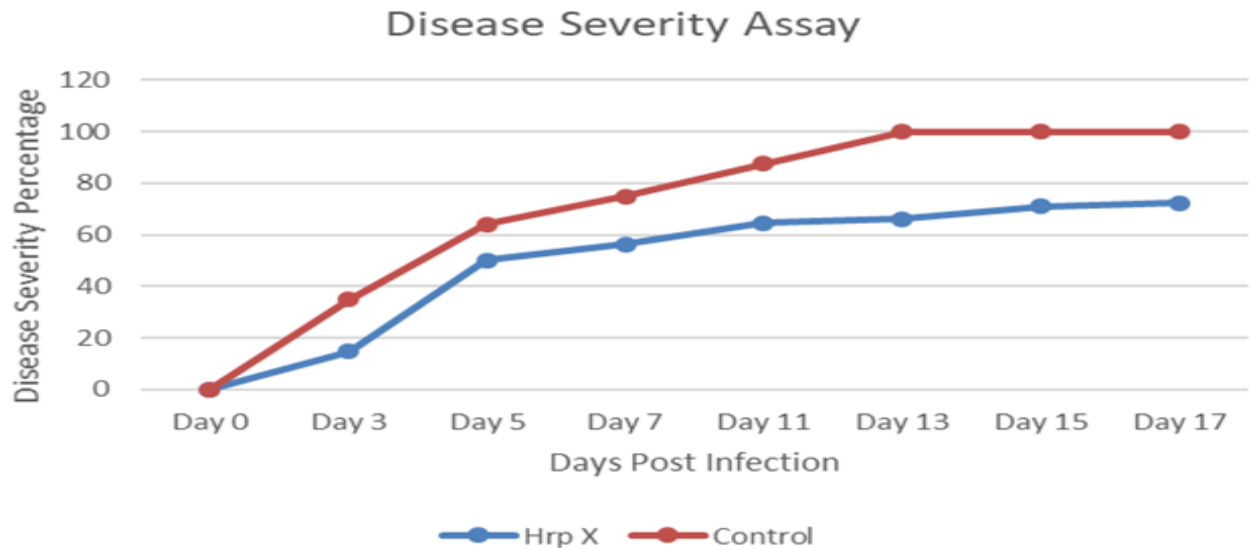

Figure 4. Disease severity analysis for assessment of the effect of recombinant HRPX treatment on papaya plants.

To investigate the effect of HRPX protein on the expression levels of defense-related genes, HRPX-sprayed and control leaves were harvested/collected and their expression was analyzed via real-time PCR. Leaf sampling was conducted one day after the third application of HRPX foliar spray treatment, when RNA was extracted (Figure 5A). The selected genes were NPR, PRIB, Osmotin, and PRID. Overall, profiling analysis showed that all four genes were upregulated in response to HRPX treatment as compared to control (Figure 5B). The highest expression was recorded for $P R 1 D$, with $\sim 13$-fold expression in HRPX-treated plants compared to control. PRIB and NPR also showed significant increase in expression ( 2- to 2.8-fold) in HRPX-treated plants, whereas an insignificant increase was seen for Osmotin, with $\sim 1.7$-fold expression. NPR, PRIB, Osmotin, and PRID are pathogenesis-related genes previously reported as potential SAR markers (Abu Bakar et al., 2018). The activation of SAR markers suggested that HRPX recombinant protein had induced papaya plant resistance via a SAR mechanism. With regard to to DS scoring, Figure 4, and the profiling of SAR-responsive genes, this result suggested that HRPX activates the SAR response against papaya dieback pathogen but is unable to enhance plant survival since it is a regulatory protein that does not directly interact with the host. It has been reported that in several necrogenic bacteria, including Erwinia and Pantoea, HRPX is one of two key regulatory genes (HRPXY) that are required/vital for activation of the expression of hrp operons, which will finally result in activation of promoters containing hrp boxes (e.g., the hairpin water-soaking wts and hrp secretion genes) (Merighi et al., 2003; Zhao, Wang, Nakka, Sundin, \& Korban, 2009). 
A.

$\begin{array}{lllllll}\mathrm{C} 1 & \mathrm{C} 2 & \mathrm{C} 3 & \mathrm{X} 1 & \mathrm{X} 2 & \mathrm{X} 3\end{array}$

B.
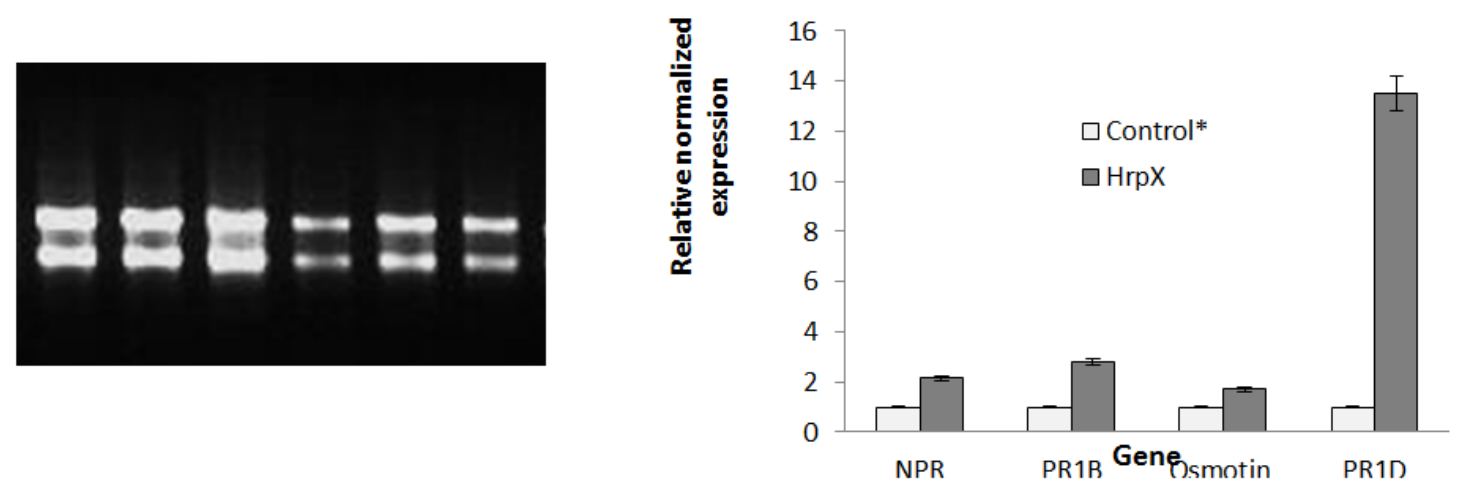

Figure 5. (A) RNA extracted from control (C1-C3) and treated (X1-X3) plants. (B) Expression analysis of papaya defenserelated genes in control plants (non-sprayed) and recombinant HRPX foliar-sprayed plants.

The usage of recombinant protein to induce a hypersensitive response and SAR in tobacco was reported by Shen et al. (2019). In their research, a novel effector from Bacillus subtilis BU412, which was produced as recombinant protein, was shown to increase the production of reactive oxygen species $\left(\mathrm{H}_{2} \mathrm{O}_{2}\right.$ and $\left.\mathrm{O}_{2}^{-}\right)$along with that of tobacco plant defense enzymes. Similar findings were recorded by Fontanilla et al. (2005) when tomato plants were sprayed with Harpin (Ea). Plants infected by Phytophora infestans developed higher tolerance to the pathogen after subsequent foliar application of the protein (Fontanilla, Montes, \& De, 2005).

Thus, for our future research, the expression conditions for HRPX will be optimized and the parameters determined for increased resistance against papaya dieback disease using recombinant HRPX. Concurrently, we will also assess the underlying mechanisms of HRPX stimulation in plant defense responses against papaya dieback disease for future application of the protein in the management of this disease.

\section{CONCLUSIONS}

Erwinia mallotivora HRPX was analyzed via in silico analysis, cloned, and expressed in an E. coli system and investigated to determine its ability to induce SAR in the management of papaya dieback disease. Foliar application of the HRPX recombinant protein was tested to evaluate its effectiveness in inducing SAR in papaya for enhanced disease resistance to the papaya dieback pathogen. Disease progression data recorded for disease severity assay indicate that plants thus treated were more tolerant to E. mallotivora infection, with reduced disease symptoms compared to control plants. Thus, HRPX has the potential for use as part of SAR inducer formulation in the fight to revitalize the Malaysian papaya industry against the notorious papaya dieback disease.

Funding: This study was funded by a Malaysian Agricultural Research and Development
Institute (MARDI) Development Research grant, no. PRB405.
Competing Interests: The authors declare that they have no competing interests.
Contributors/Acknowledgement: All authors participated equally in the design and
performance of the current research.
Views and opinions expressed in this study are those of the authors views; the Asian Journal of
Agriculture and Rural Development shall not be responsible or answerable for any loss, damage,
or liability, etc. caused in relation to/arising out of the use of the content.

\section{REFERENCES}

Abu Bakar, N., Badrun, R., Rozano, L., Ahmad, L., Mohd Raih, M. F. R., \& Tarmizi, A. A. (2017). Identification and validation of putative Erwinia mallotivora effectors via quantitative proteomics and Real time analysis. Journal of Agriculture and Food Technology, 7(9), 10-21.

Abu Bakar, N., Mohd Zulfadli, S., Juri, N. M., \& Johari, S. (2018). Induction of systemic acquired resistance in Papaya by foliar Application of HrpN Recombinant Protein for Increased Resistance against Papaya Dieback Pathogen. Current Investigations in Agriculture and Current Research, 2, 195-202.

Ahmad, R. R., Abu Bakar, N., Rozano, L., Badrun, R., Amin, N. M., \& Raih, M. F. (2014). Draft genome sequence of Erwinia mallotivora BT-MARDI, causative agent of papaya dieback disease. Genome Announcement, $2(3)$, e00375.

Alfano, J. R., \& Collmer, A. (2004). Type III secretion system effector proteins: Double agents in bacterial disease and plant defense. Annual Review of Phytopathology, 42(1), 385-414.Available https://doi.org/10.1146/annurev.phyto.42.040103.110731.

Anon. (2009). Dead papaya disease. Retrived from: http://www.moa.gov.my/web/guest/penyakitmati_rosotbetik.

Anuar, N. S., Zahari, S. S., Taib, I. A., \& Rahman, M. T. (2008). Effect of green and ripe Carica papaya epicarp extracts on wound healing and during pregnancy. Food and Chemical Toxicology, 46(7), 2384-2389.Available at: https://doi.org/10.1016/j.fct.2008.03.025.

Aziz, J., Kassim, N. L. A., Kasim, N. H. A., Haque, N., \& Rahman, M. T. (2015). Carica papaya induces in vitro thrombopoietic cytokines secretion by mesenchymal stem cells and haematopoietic cells. BMC Complementary and Alternative Medicine, 15(1), 1-8.Available at: https://doi.org/10.1186/s 12906-015-0749-6. 
Bektas, Y., \& Eulgem, T. (2015). Synthetic plant defense elicitors. Frontiers in Plant Science, 5, 804.Available at: $10.3389 /$ fpls.2014.00804.

Birkenbihl, R. P., Liu, S., \& Somssich, I. E. (2017). Transcriptional events defining plant immune responses. Current Opinion in Plant Biology, 38, 1-9.Available at: https://doi.org/10.1016/j.pbi.2017.04.004.

Bradford, M. M. (1976). A rapid and sensitive method for the quantitation of microgram quantities of protein utilizing the principle of protein-dye binding. Analytical Biochemistry, 72(1-2), 248-254.Available at: https://doi.org/10.1016/00032697(76)90527-3.

Cao, H., Glazebrook, J., Clarke, J. D., Volko, S., \& Dong, X. (1997). The arabidopsis NPR1 gene that controls systemic acquired resistance encodes a novel protein containing ankyrin repeats. Cell, 88(1), 57-63.Available at: https://doi.org/10.1016/s0092-8674(00)81858-9.

Chan, Y. K., \& Baharuddin, A. G. (2010). Rejuvenating the flagging papaya industry in Malaysia: the role of MAFC. Paper presented at the Paper presented at II International Symposium on Papaya. Acta Horticulture.

Chen, H., Chen, J., Li, M., Chang, M., Xu, K., Shang, Z., . . McGill, J. (2017). A bacterial type III effector targets the master regulator of salicylic acid signaling, NPR1, to subvert plant immunity. Cell Host \& Microbe, 22(6), 777-788. e777.Available at: https://doi.org/10.1016/j.chom.2017.10.019.

Chern, M., Fitzgerald, H. A., Canlas, P. E., Navarre, D. A., \& Ronald, P. C. (2005). Overexpression of a rice NPR 1 homolog leads to constitutive activation of defense response and hypersensitivity to light. Molecular Plant-Microbe Interactions, 18(6), 511-520.Available at: https://doi.org/10.1094/mpmi-18-0511.

Dangl, J. L., Horvath, D. M., \& Staskawicz, B. J. (2013). Pivoting the plant immune system from dissection to deployment. Science, 341(6147), 746-751.Available at: https://doi.org/10.1126/science.1236011.

Dharmarathna, S. L. C. A., Wickramasinghe, S., Waduge, R. N., Rajapakse, R. P. V. J., \& Kularatne, S. A. M. (2013). Does Carica papaya leaf-extract increase the platelet count? An experimental study in a murine model. Asian Pacific Journal of Tropical Biomedicine, 3(9), 720-724.Available at: https://doi.org/10.1016/s2221-1691(13)60145-8.

Evans, E. A., \& Ballen, F. H. (2012). An overview of global Papaya production, trade, and consumption, food and resource economics department, UF/IFAS Extension (pp. 1-4). Publication No. FE 913 (2015).

Fontanilla, J., Montes, M., \& De, R. P. (2005). Induction of resistance to the pathogenic agent Botrytis cinerea in the cultivation of the tomato by means of the application of the protein" Harpin"(Messenger). Communications in Agricultural and Applied Biological Sciences, 70(3), 35-40.

Fontanilla, M., Montes, M., \& De, R. P. (2005). Effects of the foliar-applied protein" Harpin (Ea)"(messenger) on tomatoes infected with Phytophthora infestans. Communications in Agricultural and Applied Biological Sciences, $70(3), 41-45$.

Fu, Z. Q., \& Dong, X. (2013). Systemic acquired resistance: Turning local infection into global defense. Annual Review of Plant Biology, 64(1), 839-863.Available at: https://doi.org/10.1146/annurev-arplant-042811-105606.

Gao, Q. M., Zhu, S., Kachroo, P., \& Kachroo, A. (2015). Signal regulators of systemic acquired resistance. Frontiers in Plant Science, 6, 228.Available at: 10.3389/fpls.2015.00228.

Gardan, L., Christen, R., Achouak, W., \& Prior, P. (2004). Erwinia papayae sp. nov., a pathogen of papaya (Carica papaya). International Journal of Systematic and Evolutionary Microbiology, 54(1), 107-113.

Göhre, V., \& Robatzek, S. (2008). Breaking the barriers: Microbial effector molecules subvert plant immunity. Annual Review of Phytopathology, 46(1), 189-2 15.Available at: https://doi.org/10.1146/annurev.phyto.46.120407.1 10050.

Jones, J. D., \& Dangl, J. L. (2006). The plant immune system. Nature, 444(71117), 323-329.

Jung, H. W., Tschaplinski, T. J., Wang, L., Glazebrook, J., \& Greenberg, J. T. (2009). Priming in systemic plant immunity. Science, 324(5923), 89-91.

Juri, N. M., Samsuddin, A. F., Abdul Murad, A. M., Tamizi, A. A., Shaharuddin, N. A., \& Abu-Bakar, N. (2020). Discovery of pathogenesis related and effector genes of Erwinia mallotivora in Carica papaya (Eksotika I) Seedlings via Transcriptomic Analysis. International Journal of Agriculture and Biology, 23(5), 102 1-1032.

Kim, H. S., \& Delaney, T. P. (2002). Over-expression of TGA5, which encodes a bZIP transcription factor that interacts with NIM1/NPR1, confers SAR-independent resistance in Arabidopsis thaliana to Peronospora parasitica. The Plant Journal, 32(2), 151-163.Available at: https://doi.org/10.1046/j.1365-313x.2001.01411.x.

Kim, J.-G., Jeon, E., Oh, J., Moon, J. S., \& Hwang, I. (2004). Mutational analysis of Xanthomonas harpin HpaG identifies a key functional region that elicits the hypersensitive response in nonhost plants. Journal of bacteriology, 186(18), 62396247.Available at: https://doi.org/10.1128/jb.186.18.6239-6247.2004.

Liu, R., Lü, B., Wang, X., Zhang, C., Zhang, S., Qian, J., \& Dong, H. (2010). Thirty-seven transcription factor genes differentially respond to a harpin protein and affect resistance to the green peach aphid in Arabidopsis. Journal of Biosciences, 35(3), 435-450.Available at: https://doi.org/10.1007/s12038-010-0049-8.

Merighi, M., Majerczak, D. R., Stover, E. H., \& Coplin, D. L. (2003). The HrpX/HrpY two-component system activates hrpS expression, the first step in the regulatory cascade controlling the Hrp regulon in Pantoea stewartii subsp. stewartii. Molecular Plant-Microbe Interactions, 16(3), 238-248.Available at: https://doi.org/10.1094/mpmi.2003.16.3.238.

Mohd Taha, M. D., Mohd Jaini, M. F., Saidi, N. B., Abdul Rahim, R., Md Shah, U. K., \& Mohd Hashim, A. (2019). Biological control of Erwinia mallotivora, the causal agent of papaya dieback disease by indigenous seed-borne endophytic lactic acid bacteria consortium. PloS one, 14(12), e0224431.Available at: https://doi.org/10.1371/journal.pone.0224431.

Noriha, A., Hamidun, B., \& Indu, B. (2011). Erwinia mallotivora sp. a new pathogen of papaya (Carica papaya) in Peninsular Malysia. International Journal of Molecular Science, 12(1), 39-45.Available at: https://doi.org/10.3390/ijms 12010039.

Norliza, A. B., Rafidah, B., \& Mohd, Z. S. (2016). Characterization of pathogenesis related (PR) genes expression associated with disease resistance for the establishment of systemic acquired resistance marker. Paper presented at the Plant Genomic Congress Asia. Kuala Lumpur, Malaysia.

Otsuki, N., Dang, N. H., Kumagai, E., Kondo, A., Iwata, S., \& Morimoto, C. (2010). Aqueous extract of Carica papaya leaves exhibits anti-tumor activity and immunomodulatory effects. Journal of Ethnopharmacology, 127(3), 760-767.Available at: https://doi.org/10.1016/j.jep.2009.11.024.

Rabu, M. R., \& Mat, L. R. (2005). Prospect of papaya in the world market: Malaysia perspective. Paper presented at the Proceeding of First International Symposium on Papaya, Genting Higlands, Malaysia. 
Samsuddin, N. H., Abu Bakar, N., Shaharuddin, N. A., Mohamad, A. A., Laboh, R., Badrun, R., \& Muhamad, N. A. A. (2018). Establishment of systemic acquired resistance (SAR) in papaya by external salicylic acid application as a strategy to control dieback disease. International Journal of Current Research, 10(10), 4440-74448.

Shen, Y., Li, J., Xiang, J., Wang, J., Yin, K., \& Liu, Q. (2019). Isolation and identification of a novel protein elicitor from a Bacillus subtilis strain BU412. AMB Express, 9(1), 117.Available at: 10.1186/s13568-019-0822-5.

Zhao, Y., Wang, D., Nakka, S., Sundin, G. W., \& Korban, S. S. (2009). Systems level analysis of two-component signal transduction systems in Erwinia amylovora: Role in virulence, regulation of amylovoran biosynthesis and swarming motility. BMC Genomics, 1O(1), 245.Available at: https://doi.org/10.1186/1471-2164-10-245. 